\title{
The Counter-performativity of Calculative Practices Mobilising Rankings of Intellectual Capital
}

Boedker, Christina; Chong, Kar Ming; Mouritsen, Jan

Document Version

Accepted author manuscript

Published in:

Critical Perspectives on Accounting

DOI:

10.1016/i.cpa.2019.102100

Publication date:

2020

License

CC BY-NC-ND

Citation for published version (APA):

Boedker, C., Chong, K. M., \& Mouritsen, J. (2020). The Counter-performativity of Calculative Practices:

Mobilising Rankings of Intellectual Capital. Critical Perspectives on Accounting, 72, [102100].

https://doi.org/10.1016/j.cpa.2019.102100

Link to publication in CBS Research Portal

\section{General rights}

Copyright and moral rights for the publications made accessible in the public portal are retained by the authors and/or other copyright owners and it is a condition of accessing publications that users recognise and abide by the legal requirements associated with these rights.

Take down policy

If you believe that this document breaches copyright please contact us (research.lib@cbs.dk) providing details, and we will remove access to the work immediately and investigate your claim. 


\section{The Counter-performativity of Calculative Practices: Mobilising Rankings of Intellectual Capital}

\section{Christina Boedker, Kar Ming Chong, and Jan Mouritsen}

Journal article (Accepted manuscript*)

\section{Please cite this article as:}

Boedker, C., Chong, K. M.., \& Mouritsen, J. (2019). The Counter-performativity of Calculative Practices: Mobilising Rankings of Intellectual Capital. Critical Perspectives on Accounting, [102100]. https://doi.org/10.1016/j.cpa.2019.102100

\section{DOI: 10.1016/j.cpa.2019.102100}

* This version of the article has been accepted for publication and undergone full peer review but has not been through the copyediting, typesetting, pagination and proofreading process, which may lead to differences between this version and the publisher's final version AKA Version of Record.

Uploaded to CBS Research Portal: May २०२०

(C) 2019. This manuscript version is made available under the CC-BY-NC-ND 4.0 license http://creativecommons.org/licenses/by-nc-nd/4.0/ 


\title{
The Counter-performativity of Calculative Practices: Mobilising Rankings of Intellectual Capital
}

\author{
Christina Boedker a, Kar-Ming Chong b, Jan Mouritsen c \\ a Quadrangle Building, Room 3072, School of Accounting, UNSW Business School, \\ University of New South Wales, Anzac Parade, Kensington, NSW 2052, \\ Sydney, Australia \\ b Quadrangle Building, Room 3096, School of Accounting, UNSW Business School, \\ University of New South Wales, Anzac Parade, Kensington, NSW 2052, \\ Sydney, Australia \\ c Copenhagen Business School, Solbjerg Plads 3, DK 2000 Copenhagen, Room: \\ SOL/B5.04, Denmark
}

\begin{abstract}
This article investigates accounting as a counter-performative practice. For two years and nine months, we followed State Corporation, which participated in a ranking exercise using the Intellectual Asset Health Check launched by the Australian Federal Government in 2010. We find that sceptical employees seized the opportunity made possible by the ranking system to air alternative strategies. Rather than working in a predictable or performative manner, the ranking system was taken out of the hands of management and used against them. The study contributes to extant literatures by showing how accounting can become a tool to mount and sustain resistance. The ranking system, and the ideology it represented, became counter-productive because it produced effects that were 'counter' or contrary to its own intent and ideals.
\end{abstract}

Keywords: Counter-performativity; ranking; intellectual assets, resistance. 


\section{Introduction}

This paper examines the role of accounting in transforming an Australian public sector organisation from a tangible asset company to a knowledge-based company. Prior research shows that an accounting system is considered a powerful force, which can help constitute an organisation in its image (e.g. MacKenzie, 2007; Miller, 1991). For example, accounting can be a vehicle for the introduction of principles of New Public Management that challenge the professional and ethical norms of public servants to the detriment of service quality (Ferlie, Pettigrew, Ashburner, \& Fitzgerald, 1997; Hyndman \& Lapsley, 2016). Even if public sector servants attempt to resist this agenda (Fischer \& Ferlie, 2013), their efforts are often in vain because accounting is too powerful. Accounting can drive out competing concerns and values and its calculative logics are often stronger than professional logics (Oakes, Townley, \& Cooper, 1998). To withstand accounting is difficult, even impossible.

Such an approach to understanding accounting phenomena focuses on the transformations that happen as an implication of accounting tools and devices. This is generally referred to as transformative, or performative, approach to investigating economic calculations and models (e.g. MacKenzie, 2007). The claim is that accounting 'provokes' (Muniesa, 2014) people to act and provides a language and tools for transforming social arrangements (Oakes et al., 1998) and for making political processes possible that then help constitute organisations.

Within accounting research, there are at least two literatures in which accounting has been attributed transformative powers, being the performativity literature and the incompleteness literature. These two literatures differ in the degree of performative power they assign to calculative models and accounting systems. For example, the literature on performativity suggests that accounting and calculative 
models are engines that transform human activity rather than cameras that merely record what humans do (MacKenzie, 2006). Once the economic model or calculation is in place, proposed effects will follow. Here, there is a high degree of certainty that accounting will achieve its stated aims. Accounting models and techniques make individuals calculating agents in pursuit of the ambitions inscribed by accounting (e.g. Miller, 1991). This is an outcome-oriented approach to investigating the efficacy of calculative practices (e.g. Sauder \& Espeland, 2009).

The incompleteness literature is less deterministic and suggests that accounting can be ambiguous and convey less than what managers would desire (Busco \& Quattrone, 2015, 2018; Jordan \& Messner, 2012; Jørgensen \& Messner, 2010; Wouters \& Wilderom, 2008). Accounting is 'lacking'. When accounting is considered less than a full representation of the world, managers have to add substantial resources to make it work. They find short cuts and develop strategies to make more out of accounting than it proposes. Because accounting is frail (Chua, 1995), unstable (Dambrin \& Robson, 2011) and incomplete (Busco \& Quattrone, 2015), managers improvise and adapt in order to make accounting work (see also, Andon, Baxter, \& Chua, 2007; Quattrone \& Hopper, 2005). Here, the incompleteness of accounting lures managers into repair activity (Ahrens \& Chapman, 2004). This is a process of considerable uncertainty - and in contrast to the performativity research - the incompleteness strand acknowledges that accounting will start things, but also that its effects are more uncertain and contingent. Instead of 'strong' or 'complete' accounting numbers, managers need to complement accounting with other things to make it useful (Jordan \& Messner, 2012).

Thus, while the literature on performativity typically focuses on how accounting provides direction and is related to outcomes, the incompleteness literature focuses on 
how accounting starts a process of inquiry. Both literatures however share an appreciation that accounting is powerful and operates as a force that propels individuals along a more or less set path. Although within the incompleteness literature there are detours and deviations, accounting will eventually bring into line those agents who have gone astray. As such, there are only productive detours and even if things go awry, this is often for the better and ultimately serves to strengthen the role of accounting.

However, neither of these two literatures considers that accounting can also produce effects that are 'counter', or contrary, to its own utterances or ideals. In other words, accounting systems and calculations may also be counter-performative. MacKenzie (2007, p. 55) identifies counter-performativity as the process by which the "practical use of a calculative model makes economic or organisational processes less like their depiction". This is where accounting can produce behaviours that may eventually undermine its own purposes. For example, MacKenzie (2007) observes that while the Black-Scholes model of option pricing seemed to initially perform well, it was not able to sustain that effect over time. Indeed, over time, mobilising the model moved option prices in the market further away from those proposed by the model. Callon (2007) similarly suggests that counter-performativity occurs when an economic model becomes invalid; that is, when the calculative device fails to maintain continuity and produces behaviours that eventually undermine it. This does not mean that accounting 'misfires' in the sense of not working or not ascribing effects (Callon, 2010), but in the sense that it produces effects that are contrary to those proposed by accounting itself. Following Hines (1988), this means that not only will no one abide by accounting's communication, if it can be heard at all (Hopwood, 1972; Munro, 1995), but that accounting helps produce effects that are contrary to its communication. 
This study investigates a particular calculative practice or accounting device - namely a ranking system - in a public sector organisation. Specifically, the study aims to extend prior literatures on performativity and incompleteness to examine the notion of counterperformativity and to identify the conditions that can contribute to the mobilisation of an agenda of counter-performativity. The study achieves this through a case study of the implementation of a ranking system by an Australian public sector organisation. Ranking is the practice of comparing entities' performance with each other and then ranking this relative performance to identify best (or worst) performers. Institutions most often want to know their relative performance and seek to 'climb the rank' and 'reach the top'. This is a well-known effect of ranking systems, as demonstrated in the studies of ranking MBA school (Free, Salterio, \& Shearer, 2009; Hazelkorn, 2015; Marginson \& van der Wende, 2007; Wedlin, 2011). Ranking also happens in executive compensation contracts where salary depends less on achieving pre-determined targets, and more on the performance relative to market development (Aggarwal \& Samwick, 1999; Carter, Ittner \& Zechman, 2009; Gibbons \& Murphy, 1990); and it happens in methods such as Beyond Budgeting where budgets are substituted by continuous comparison with markets (Bourmistrov \& Kaarbøe, 2013).

The case study organisation that we follow in this study used a ranking system to compare itself with other firms and institutions to get a measure of its success in implementing a new intellectual asset strategy. As a water producing company, historically, the organisation had strong identities in the tangible / material assets under its control, but a new strategy suggested intangible assets to be more important. The ranking system, which was called the Intellectual Capital Health Check, gave the organisation a visualisation of its relative performance on a series of intellectual asset measures that caused its executives to produce a strategy to elevate itself in the ranking. 
Executives suggested that this new strategy would shift the organisation's focus from tangible asset towards intangible assets. However, as will be demonstrated in the case, the ranking system not only failed to achieve this intent; it became counterperformative. The case is thus an unusual case because it shows how the ranking system did not produce the performative effects that it set out to achieve. Indeed, the system produced effects that were contrary to the ideals of its own measurement criteria. This is contrary to the idea of performativity theory, which would predict that having a measure of intellectual capital would bend people towards realising such a strategy. It is also contrary to incompleteness theory, which would predict that the flaws or deficiencies of the system would cause repair activity. Contrary to such expectations, this study shows that, in the Australian case, the ranking system motivated processes of resistance and seemed to weaken the organisation's strategy and decrease its ranking results.

The study makes two contributions. First, it shows how accounting became a tool of resistance mounted by those in opposition to the intellectual asset strategy. In prior studies, the absence of tools and devices to mount resistance has mostly been a source of weakness. Often, those with good ethics seem unable to create a fortress of inscriptions against powerful others because they have no means with which to engage in a combat - they have no ammunition; they have no accounting. Except from a few rare cases (Andrew \& Cahill, 2017), where accounting is ascribed an actual (Amernic, 1985; Cooper \& Essex, 1977; Owen \& Lloyd, 1985) or a potential (Cooper \& Sherer, 1984) role in collective bargaining, accounting is often absent in sustaining resistance. This study adds to these prior literatures by showing how accounting became a tool to mount and sustain resistance to management's strategy. This was not a situation where management could dominate labour via accounting 
systems and performance measures (Ezzamel, Willmott, \& Worthington, 2004, 2008). Instead, the system was turned on its head, taken out of the hands of management and used against them.

Second, the study traces conditions that can contribute to the mobilisation of an agenda of counter-performativity. In the Australian case, there was no market place where institutions would compete for the visibility and credibility created by public rankings. Therefore, there was no anxiety about market reputations or market demands, as was the case, for example, in the Law Schools study by Espeland \& Sauder (2007, 2016). As such, counter-performativity ensued in part from a lack of external scrutiny. Furthermore, in the Australian case, the ranking system ignored important tangible assets that were cherished by employees and this caused staff to see the ranking system as lacking in respect. Employees therefore discarded the idea put forth by the system and resisted and deconstructed all that it stood for. In response, employees developed an even stronger narrative of the primacy of tangible assets and sought to sustain its associated culture. In this situation, counter-performativity ensued because the ranking, by being incomplete, was so clearly missing things of importance to the organisation, thus rallying individuals around the things that were absent. As such, the ranking failed because it framed too little.

\section{Relevant Literatures}

\subsection{The Performativity of Accounting}

Performativity is derived from Austin's (1962) distinction between two linguistic forms: declarative and performative sentences. Declarative sentences claim to describe the world while performative sentences bring about the world. The phrase, "It is raining", can be understood as describing a phenomenon, while a priest's 
declaration, 'I pronounce you wife and husband', brings a marriage into existence. There are institutional conditions for the priest being able to utter this statement with such power, but here, it is sufficient to say that stating things may produce them. As Hines (1988, p. 251) suggests, "in communicating reality, we construct reality."

The notion of performativity is recent to accounting research but it is not unknown given long-standing acceptance that accounting is constitutive of action (Burchell, Clubb, Hopwood, Huges, \& Nahapiet, 1980). The idea is that accounting, its language, categories, and values, help design the work and actions of institutions and economic agents. Accounting provides language, motives and means that make actors act and react. As Burchell et al. (1980, p. 24) noted:

"Consideration would need to be given to the roles which information and accounting play in the political processes which characterize organizational and social life, to those forces which have constituted the organization as we now know it and to the ways in which the social and the organization in accounting intertwine with each other."

Performativity has been applied widely in the sociology of finance (e.g. MacKenzie, 2006; Callon, 1998, 2007) and has later been brought into accounting. The accounting thesis is that performativity requires tools, or calculative practices, to work, many of which are best understood as being provided by the accounting function. Thus, accounting is not primarily interesting for its potential capacity to describe the world, but for its capacity to constitute the world. As Callon (1998, p. 23) observes:

"To show the capacity of economics in the performing (or what I call 'performation') of the economy, we have to start between the two with the set of calculating tools without which calculative agency would not be possible... Calculativeness couldn't exist without calculating tools. Consequently and in order to understand how they work, full significance has to be restored to that humble, disclaimed and misunderstood practice: accounting and the tools it elaborates."

Accounting enables calculativeness (Callon, 1998) by turning ordinary people into calculative agents (Miller, 2001). Accounting provides a language and motive via the 
things it makes visible, and then it sustains individuals as calculating agents on that basis. Calculative techniques are however not only tools for framing people's thinking; they are also persuasive, even seductive, devices since they shape people's world and lure people into their world. People find it difficult to resist being drawn in by the tools of accounting as they are their window to the world. It is by such mechanisms that individuals can make sense of, and act on, a world that would otherwise be confusing (Latour, 1986). Thus, when accounting is performative, it is understood to influence the thinking of and dialogues among managers (Boedker \& Chua, 2013; Busco \& Quattrone, 2018;; Cushen, 2013; Dambrin \& Robson, 2011; Miller \& Power, 2013; Mouritsen \& Kreiner, 2016; Skærbæk \& Tryggestad, 2010; Themsen \& Skærbæk, 2018; Vosselman, 2014). In this sense, accounting produces powerful individuals, who organise their lives according to the scripts of accounting.

Yet, as MacKenzie (2007) argues, not all knowledge is successfully performative; and conditions of felicity ${ }^{1}$ are not always in place (see also Austin, 1962; Callon, 2007; Lépinay, 2007). Sometimes calculative practices and models may not work as intended partly because people are not effectively lured by them and partly because sometimes other agents produce and mobilise calculative practices or antiprograms that may be stronger than the one in question. Laboratories compete (Latour, 1987) just as calculations compete (Mouritsen, Hansen, \& Hansen, 2009) for attention and during such competitions, someone inevitably loses. Thus, the engine of calculation is performative only by degrees and with caveats. This is important for the present

\footnotetext{
${ }^{1}$ Performative statements cannot be evaluated in terms of truth but may instead be in terms of 'felicity', i.e., whether the realisation of the utterance happens. Consequently, for the statement 'I pronounce you husband and wife' to be felicitous, it is necessary that the person who pronounces the statement is accorded a social role that makes others follow the statement. Not everybody can legitimately make this statement; therefore, it is only performative if it is produced by, let us say, a priest.
} 
study, which attempts to delineate what it means when performativity fails and when counter-performativity reigns.

\subsection{The Ranking Literature: The Performativity of Accounting}

Performativity theory suggests that accounting calculations and models are engines that transform the world rather than cameras, which produce a representation of the world (MacKenzie, 2007). This point is best illustrated in studies of ranking systems and benchmarking. Ranking is the practice of comparing entities' performance with each other and, in so doing, identifying best and worst performers. Scott \& Orlikowski (2012, p. 26) suggest that on the one hand, ranking systems make organisations more accountable to their constituencies by rendering information about operations available and accessible. On the other hand, ranking systems give rise to anxiety as scrutiny and surveillance intensifies, and organisations become focused on accounting measures rather than on the qualities that the measures are intended to assess.

Organisations across a wide range of industries are users of ranking systems. Examples include higher education institutions (Free et al., 2009; Hazelkorn, 2015; Marginson \& van der Wende, 2007), travel and holiday companies (Jeacle \& Carter, 2011; Scott \& Orlikowski, 2012), arts, film and music organisations (Becker, 1984; Karpik, 2010; Shrum, 1996;), restaurants (Antal, Hutter, \& Stark, 2015; Blank, 2006), consumer product organisations (Aldridge, 1994), marketing / reputation companies (Pollock \& D'Adderio, 2012; Pollock, D’Adderio, Williams, \& Leforestier, 2018; Pollock \& Williams, 2009; Schultz, Mouritsen, \& Gabrielsen, 2001), hospitals 
(Llewellyn \& Northcott, 2005; Booth, James, \& Stevanovic, 2005) and even cities, which are measured as 'best places' to live and work (Kornberger \& Carter, 2010).

In their seminal study, sociologists Espeland \& Sauder (2007) show that rankings of Law Schools in America made these schools interested in transforming themselves in the image of the criteria that the ranking system defined as elite. The ranking system (referred to as the $\mathrm{USN}^{2}$ ) was important because Law Schools compete for students and research grants, and their successes (or failures) depend upon the quality criteria measured by the system. Even if only few Law Schools believed in the coherence and relevance of the ranking system (designed by a local trade journal), managers acted on it and wanted to increase their position in the rank. Gradually, managers of Law Schools grew to appreciate the ranking system, which persuaded them about the 'right' properties of Law School strategy. Over time, they became willing agents in the pursuit of ranking success. Espeland \& Sauder (2007, p. 24) suggest:

"At several schools, mathematically sophisticated faculty have gone so far as to "reverse engineer" the rankings formulas to learn how their school might improve their scores. One dean said: "We've done a lot of careful studying of the USN methodology to figure out what counts the most and what is perhaps the most manipulable, because those are not necessarily the same things." Reactions of students, alumni, media, and peers gradually "taught" law school administrators that rankings mattered. As this lesson spread, more people began treating improved rankings as a strategic project, and their influence widened. So, despite the deep skepticism most administrators still feel toward rankings, they have become crucial professional and organizational facts that generate enormous attention and effort."

This quotation shows that the ranking system provoked managers in Law Schools to act to conform to its statement. In other words, the ranking system had performative effects on the activities of managers inside Law Schools. Managers quickly learned what counted towards ranking success and even if they initially resisted, they had to abide by these factors to remain competitive. The ranking system started to work on

\footnotetext{
${ }^{2}$ The ranking system is called the U.S. News and World Report (and abbreviated USN).
} 
managers even though they knew it was wrong and even when they developed what they otherwise considered wrong decisions. As Locke (2011, p. 26) says: "All the things wrong with rankings matter considerably less than the plain fact that rankings matter". Analytical deficiency "does not rob rankings of their power" (Marginson \& van der Wende, 2007, p. 309). Indeed, ranking systems work even if they only have few referential qualities. As such, a ranking system is not a description of the world, but it brings about a whole new world. And that is what makes such calculative systems powerful.

However, rankings have been criticised on a number of dimensions. For example, they encourage a single model of performance and produce 'averageness'. The risk of ranking is that it diminishes "the salience of local knowledge and professional autonomy" and "absorbs vast resources and insinuate and extend market logic" (Sauder \& Espeland, 2009, p. 79). This point is illustrated within higher education, where the standard provided by ranking systems has developed into an industry 'norm' and been criticised for producing a single model of education without addressing whether ranking world class universities meets the wider needs of society (Hazelkorn, 2015). This also happens in hospitals where ranking and benchmarking practices tend to create 'average', or even standardised, organisations (Llewellyn \& Northcott, 2005). Rankings filter, make and disseminate knowledge that constitute organisations as distinctive objects amenable to certain manipulations, even though rankings initially were intended to evaluate organisations, not change them. This potentially threatens not only to "flatten out variety" among organisations but also to hamper creative thinking among professionals in a field (Grey, 2009, p. 355). Wedlin (2011, p. 214) warns against such standardisation and suggests: 
"... as the rankings are becoming increasingly accepted and even institutionalised as measures of success within fields, it becomes more difficult to break with the norms and expectations conveyed through them, and to challenge or question their standards and assumptions."

At the individual or personal level, the performative effects of ranking are directly linked to anxiety (Espeland \& Sauder, 2016). Rankings inevitably generate "anxiety, uncertainty, meticulous monitoring, and discipline" (Sauder \& Espeland, 2009, p. 79). People feel they must surrender to the ranking system. Once within the realm of the ranking system, they are trapped in an endless game of performance improvement that never cease to generate anxiety and fears of inferiority. Indeed, the ranking game drives the search for decisions that improves ranking positions. In the case of Law Schools, rankings create anxiety in prospective students and their parents. Students, whether admitted (or not admitted) to top tier schools, internalise their membership (or exclusion) as a sign of their personal qualities. Likewise, Law School managers experience anxiety because much is at stake and all are in doubt whether the ranking makes a reasonable claim about the quality of their particular institution and more importantly, about their individual qualities and skills as managers. On the one hand, there is the opportunity for fame and glory but on the flip side, ranking games are also characterized by a fear of 'falling in the ranks' and not living up to expectations. Thus, anxiety is driving the importance of the ranking game and makes it strong and unavoidable. Stakes are high for all involved and 'falling in the ranks' is to be avoided at all costs, even if institutions think they make wrong decisions.

A ranking system is also a mechanism that makes knowledge about the organisation available to wider segments of the population. The ranking is thus a window to the world. It presents the organisation to the public and therefore, it is pivotal in mediating between management, the organisation and the public networks and communities within which the organisation is located. This is why rankings create 
anxiety. Because they put pressure on institutions to conform to public expectations and the only way to alleviate this burden is to adhere to their measurement criteria. At the Law Schools, managers could not remain 'in the dark' because external scrutiny was unavoidable. Students, media, alumni and others took the ranking seriously and as a consequence, the ranking system made Law School managers redesign their strategies to fit the criteria bestowed upon them (Espeland \& Sauder, 2007). Here, the ranking provoked managers to perform to a point where they risked becoming appendices to the system and the criteria it upheld. In other words, ranking systems can lure managers into action because they provide reputational benefits (or costs) that aim to induce greater acceptance and endorsement by the wider community in which a firm is located.

In summary, the ranking literature is concerned with the power of ranking systems to compel firms and institutions to make substantial efforts to conform to their statements. By working on the calculative model or theory, institutions, firms and managers will, even when they disagree with it, work along with it and eventually realise it (Espeland \& Sauder, 2007; Sauder \& Espeland, 2009). It is clear that ranking systems illustrate a very strong form of performativity where managers have no choice but to react to them. The world becomes what the ranking system says. The ranking system comes first; the world comes later.

\subsection{The Performativity of 'Making Do': The Incompleteness of Accounting}

However, not all accounting research assigns as much performative power to accounting systems or numbers. In particular, the incompleteness literature suggests that accounting can be ambiguous and its effects uncertain (Busco \& Quattrone, 2015, 2018; Jordan \& Messner, 2012; Jørgensen \& Messner, 2010; Wouters \& Wilderom, 2008). Accounting is a provocateur, rather than primarily a consequence, of economic 
activity (Muniesa, 2014). When accounting is a provocateur, it typically asks, or provokes, individuals to bring change to the world (Busco \& Quattrone, 2018; Mouritsen \& Kreiner, 2016).

Incompleteness happens because accounting information does not capture all the dimensions of performance considered relevant to an organisation or a manager (Jordan \& Messner, 2012). So, there is a lack, and this lack (or incompleteness) of information, makes managers look for solutions to help them stabilise situations (Ahrens \& Chapman, 2004, 2007; Busco, Quattrone \& Riccaboni, 2007; Jordan \& Messner, 2012; Vaivio, 1999). When accounting is considered less than a full representation of the world, managers have to 'make do' with what they got at hand and often this requires them to add substantial resources to make accounting work. Accounting is thus a potential and conditional resource, which works when managers add attention to it. Accounting is in need of repair (Ahrens \& Chapman, 2004, 2007), requires tinkering (Dambrin \& Robson, 2011), judgment (Shollo, Constantiou, \& Kreiner, 2015), and experimentation (Andon et al., 2007). Through process, dialogue and discussion, incompleteness develops 'generative in-tensions' (Busco \& Quattrone, 2015, 2018; Quattrone, 2009, 2017) that produce knowledge beyond what accounting states. ${ }^{3}$ These tensions may be handled with different degrees of predictability and success. Dealing with them is a process of considerable uncertainty. Thus, and in contrast to the literature on performativity mentioned earlier, the incompleteness agenda acknowledges that accounting will start things, but that its effects are more uncertain and contingent.

\footnotetext{
${ }^{3}$ For example, Jordan and Messner (2012) show that a productivity measure prompts production managers to consider not only production matters but also markets and shareholder value. Productivity is a starting point for sense making across a variety of concerns.
} 
In summary, while literatures on performativity focuses on how accounting relates to outcomes, incompleteness research focuses on how accounting starts a process of inquiry. In the latter, performativity is not strongly orientated towards an ideal defined by accounting (as in the ranking literature). Instead, accounting is performative in the sense of provoking managers to start a process of engagement and enquiry around issues and problems (Mouritsen \& Kreiner, 2016). Here, accounting is a conditional resource, which is 'congenitally failing' (Miller \& Rose, 1990). Whilst it may provoke people to bring change to their worlds, it rarely works only in predictable ways.

However, common to both the performative and incompleteness literatures is that accounting systems are rarely seen to be counter-performative. Finding a situation where accounting is counter-performative can help understand the conditions both for performativity and counter-performativity.

\subsection{Counter-performativity and the Success of the Opposite}

Neither of the above two literatures considers the possibility that accounting can produce effects that are 'counter', or contrary, to its own utterances or ideals. In other words, accounting systems and calculations may also be counter-performative. MacKenzie (2007, p. 55) defines counter-performativity as the process by which the practical use of a calculative device makes organisational processes less like their depiction. This creates a situation where accounting produces behaviours that may eventually undermine its own purposes and directly work against them. According to Bamford \& MacKenzie (2018, p. 99):

"Counter-performativity is a very particular form of misfire, of unsuccessful framing, when the use of a mathematical model does not simply fail to produce a 
reality (e.g. market results) that is consistent with the model, but actively undermines the postulates of the model. The use of a model, in other words, can itself create phenomena at odds with the model."

By way of a practical example, MacKenzie (2007) found that while the BlackScholes model of option pricing seemed to perform well initially, it was not able to sustain this effect. Indeed, over time, mobilising the model moved options prices in the market further away from the prices proposed by the model (MacKenzie \& Millo, 2003; Millo \& MacKenzie, 2009). Another example is the 2009 Global Financial Crisis, which was created by the very processes that, according to finance theory, were supposed to mitigate the risk of financial failure (see Roberts \& Jones, 2009). Ironically, the system of performance measures and incentives invented by capitalist society ultimately caused the financial system's own demise (Cooper, 2015). In other words, the economic model produced acts that stroke back and yielded evidence that disconfirmed the science underpinning it. Assets market actors started to question their own ideology and the empirical accuracy of their economic models. Even world leading economists questioned the efficacy of their economic models; as stated by Alan Greenspan in 2008 "I found a flaw in the model that I perceived is the critical functioning structure that defines how the world works, so to speak”. Roberts \& Jones (2009) point out that we all need an ideology or conceptual framework in order to act, and it is painful, disorienting and disabling when it breaks down or fires back.

It is thus possible that accounting may not only be performative or incomplete, as suggested previously; it may also be counter-performative (MacKenzie, 2007). This means, to argue with Hines (1988), that not only will no one abide by accounting's communication, but that accounting helps produce effects that are against the very idea proposed by its own articulation. In counter-performativity, tensions occur not because there are many interests at stake but because accounting acts against its own utterances. 
It is not that outcomes vary (Quattrone \& Hopper 2001, 2005; Revellino \& Mouritsen, 2015) or are laden with overflows (Callon, 1998, 2010), but that outcomes are contradictory.

The case study that follows analyses a situation where accounting produced effects that made it counter-performative. Whilst the incompleteness of calculative technology traditionally has been found to engage users because of the organising work that it stimulates (Busco \& Quattrone, 2015), in the study that follows, the ranking system became counter-performative because it framed too little. This is important because then it is possible to understand the notion of incompleteness in a new way.

\section{Research Project and Methods}

\subsection{Research Project}

The Intellectual Asset Health Check was a ranking device constructed by the Australian government as an attempt to raise interest in workplace productivity. Policy makers called for a diagnostic benchmarking device to: (1) identify firms' performance (phase 1 of the project), and (2) to implement 'intervention strategies' to lift firms' performance (phase 2 of the project). The Intellectual Asset Health Check consisted of three separate surveys, namely an employee, Chief Financial Officer and Human Resource Management survey, totalling over 400 questions.

86 Australian organisations participated (about 5,500 respondents) in phase one of the project. The participants were service organisations with high levels of intellectual assets, operating in industry sectors such as consulting, information technology, recruitment services and legal services, and in the public sector. Five organisations participated in phase two of the project and implemented intervention strategies that aimed to improve the performance of their intellectual assets and 
workplace productivity. These organisations designed a variety of intervention strategies depending on the areas of weakness and strength identified by their Intellectual Asset Health Check benchmark report.

\subsection{Research Methods}

The organisation followed in this study is called State Corporation (a pseudonym). State Corporation is a bulk water delivery business that owns, maintains, manages and operates over thirty water dams and delivers water to thousands of licensed water users on the state's regulated rivers.

The researchers followed State Corporation for a total of two years and nine months. In March 2011, the corporation completed phase one of the Intellectual Asset Health Check and received a benchmark report. From October 2011 until July 2012, it participated in phase two of the project.

Data was collected through semi-structured interviews and participant observations. Interviews were held with ten people (see Table 1), namely four managers, four field officers and two management consultants associated with the project. The corporation was geographically spread out and researchers drove long distances into the Australian desert and outback ${ }^{4}$ through unpopulated areas with no facilities to conduct interviews with field officers, who worked on the dams. It was important to conduct the interviews with the field officers face-to-face to get a feel for their daily working lives. The interviewees were relaxed in their home environment;

\footnotetext{
${ }^{4}$ The Outback is the colloquial name for the vast, unpopulated and mainly arid areas that comprise Australia's interior and remote coasts. In Australia, the term "the Outback" is generally used to refer to locations that are comparatively more remote than those areas named "the bush" which, colloquially, can refer to any lands outside the main urban areas. The Outback regions extend from the northern to southern Australian coastlines. Geographically, the Outback is unified by a combination of factors, most notably a low human population density, a largely intact, natural environment and, in many places, low-intensity land uses in which production is reliant on the natural environment. Culturally, the Outback is deeply ingrained in Australian heritage, history and folklore.
} 
they were more talkative and forthcoming than when they were approached during their visit to the capital city for a strategy workshop (called the Fusion Day workshop).

Interviewees were asked to discuss the corporation's new intellectual asset strategy, the strategy workshops, what motivated them to start on this journey, any problems or difficulties encountered along the way, and any initiatives put into place.

\section{Table 1: Interviews}

\begin{tabular}{clcc}
\hline Interviews & Title & Date & Duration \\
\hline 1 & General Manager, Strategy and & 29 February 2012 & 62 minutes \\
& Governance & & \\
1 & Project Manager, Major Projects Group & 29 February 2012 & 26 minutes \\
1 & Manager, Dam Operations & 1 March 2012 & 96 minutes \\
1 & Senior Asset Field Officer, Dam & 1 March 2012 & 27 minutes \\
& Maintenance \& Services & & \\
1 & Asset Field Officer, Dam Maintenance \& & 1 March 2012 & 51 minutes \\
& Services & & \\
1 & Manager, Human Resources & 7 April 2012 & 26 minutes \\
1 & Manager, Customer Operations & 7 April 2012 & 57 minutes \\
1 & Senior Communications Officer & 7 April 2012 & 26 minutes \\
1 & Consultants (2 people) & 6 March 2012 & 45 minutes \\
\hline
\end{tabular}

Following Veal (2005), the researchers adopted participant observation as a research method because it is suitable in situations where complex and detailed information is required on group dynamics or interpersonal relationships. This choice of method is consistent with Perlow (1998), where the researchers acted as observers, who attended internal meetings and workshops and had informal conversations with employees during coffee and lunch breaks. Importantly, in our study, the researchers acted as observers (Veal, 2005; Perlow, 1998) not employees of State Corporation or the consulting firm. The researchers observed that in informal settings (such as chats during coffee breaks), the participants were more willing to provide information that they would have been unlikely to disclose in formal interviews and meetings. Furthermore, during participant observations, the researchers were able 
to observe the body languages and interactions of the participants, which provided insights into the informal rules and norms (Perlow, 1998) at play within the corporation. That, for example, included the sanctions deployed to negotiate and negate the new intellectual capital strategies and people's body language. Participant observations were thus an important part of the information gathering processes and critical to the researchers in forming a view of the culture and politics of the corporation and of employees' resistance to the new intellectual asset strategy.

The participant observations were carried out at two large strategy workshops hosted by State Corporation's senior management, which the researchers attended. The first workshop was the 'Fusion Day' held in February 2012. This was an organisationwide strategy workshop with 42 employees from across all geographical and functional areas of State Corporation. The workshop focused on the development and implementation of three intellectual asset strategies for the first time in the corporation's history. The second workshop was a divisional event held in April 2012 with 20 employees from the Maintenance and Services division. During this workshop, the intellectual asset strategies for this specific division were discussed and developed. Two researchers participated as observers in both workshops. During the workshops, the researchers had informal chats with the participants, for example during lunch and coffee breaks and pre-dinner drinks (Perlow, 1998). The researchers recorded their daily observations using an events diary, totalling 43 pages.

The researchers were also given permission to participate as observers in six internal meetings. These included two important one-hour meetings with the General Manager, Strategy and Governance, the Manager, Human Resources, and the CEO as well as four meetings between the managers and management consultants. During the initial two meetings, the scores reported by the Intellectual Asset Health Check 
benchmark report were discussed and the strategic themes for the corporation's upcoming corporate plan were decided on. In the following four meetings, the content and structure of the Fusion Day workshop was prepared and subsequently debriefed. The researchers conducted interviews and participant observations until we reached a point of saturation where new observations merely confirmed our interpretations and no new observations were made (Guest, Bunce, \& Johnson, 2006).

Archival documents were also collected. These included documents used in the strategy workshops, such as information booklets provided to the workshop participants, PowerPoint slides used by the presenters, and pictures drawn on walls and whiteboards by the facilitators. The researchers took 51 photos of the materials and drawings. Eleven reports and collaterals prepared by the management consultants and executive team were collected. The researchers reviewed this material during the data analysis and write-up phases. It helped the researchers reflect on the case study events by offering codified information about the corporation's new intellectual strategies. The triangulation of different data sources made it possible for the researchers to review and refine the findings, thus increasing the trustworthiness of the research.

Data analysis was initiated by converting archival data, diary notes and the audio interview files into text transcripts. The transcription process was completed by an independent third party and regularly reviewed by the researchers. Data was coded and analysed using analytical techniques, such as matrices (Miles, Huberman and Saldana, 2013), which collated and organised data in a summary format that allowed preliminary findings and themes to emerge. At times, the researchers reverted back to the participants to corroborate their accounts and interpretations provided; this also had the effect of adding credibility and affirmation to the data collected (Creswell and Miller, 2000). The main focus of the data analysis was to identify central themes and 
consistencies from the different data types. After the themes were developed, a logical analysis of the data was performed to cross-reference findings (Patton, 1990). The researchers also focused on re-generating the perspective of the participants in making sense of their own world, before researcher-centric interpretations were developed. This allowed the researchers to interpret the field "in the words of the local people, in their language, within their world view" (Patton, 1990, p. 479). This type of analysis, as well as the coding, was performed by all members of the research team in order to support the significance of the data findings (Patton, 1990).

\section{4. (Counter)performativity at State Corporation}

\subsection{The Intellectual Asset Health Check Benchmark Report}

The following sections trace State Corporation's attempts at introducing the three new intellectual assets strategies into the corporation. State Corporation operated major water infrastructure to deliver bulk water to thousands of licensed water users. Having previously been a government department, State Corporation was a standalone, state-owned corporation with an asset portfolio of billions of Australian dollars. In 2012, the corporation started to upgrade seven dams across the state, injecting hundreds of millions Australian dollars into regional community infrastructure over a five-year period.

State Corporation participated in the Intellectual Asset Health Check in March 2011. Their motivation for participating in the study was to detect whether they were 'high' or 'low' performing with regard to managing their intellectual assets when benchmarked against other Australian organisations. Significant resources were invested in the project by the senior management and the new Chief Executive Officer (CEO), who wanted to make intellectual assets a strategic priority. This included the CEO's commitment and time, financial funding of management consultants, the many 
hours invested by the project team (which included the Manager, Corporate Governance and Strategy, and others), and the participation of 59\% of the workforce in completing an online survey. 169 staff spent approximately 30 minutes each completing the survey. The Chief Financial Officer and the Human Resources Manager spent approximately two hours each completing a financial questionnaire and a human resources questionnaire. There was thus clearly a strong commitment by the corporation towards the ranking project and many resources were invested into the project.

The results from the ranking exercise were reported in a 100-page benchmark report, which was issued to the corporation's CEO on 31 May 2011. The report gave State Corporation a rank on an index which placed participants into one of the following three categories: 'High Performing', 'Mid Performing' or 'Low Performing'. The names of the participants were kept confidential and not disclosed or reported to the general public. Participants also did not know each other. These conditions meant that State Corporation's performance in the ranking system was not visible to the public. Managers at State Corporation could remain 'in the dark' and external scrutiny was avoidable. The ranking was therefore less likely to create issues of anxiety about market reputations or market demands, as was the case with the Law Schools study by Espeland \& Sauder (2007, 2016).

Figure 1 shows the radar chart provided to State Corporation in its benchmark report. It shows the corporation's results in each of the six intellectual asset categories (indicated in capital letters) and their sub-categories ${ }^{5}$. The chart was designed by IT consultants who were hired to produce the benchmark reports for the participating organisations.

\footnotetext{
${ }^{5}$ The outer line (see Figure 1) shows the average scores of all the 'High Performing Organisations'. The inner line shows the average scores of all the 'Low Performing Organisations'.
} 
Overall, State Corporation scored in the bottom quartile of the 'Mid Performing' category of the index. State Corporation ranked as 'Low Performing' in the areas of Customer Orientation and Productivity. In Leadership and Innovation, State Corporation ranked 'below average' in the 'Mid Performing' category. On Employee Experiences and Fairness, the corporation ranked 'on average' in the 'Mid Performing' Category.

One area of particular concern to the CEO was the exceptionally low level of staff participation in decision making. These results were reported later in the benchmark report. State Corporation scored 3.68 on a 7-point Likert scale for 'Employee Participation in Decision Making', compared to an average of 4.49 for all participating organisations. State Corporation scored 3.74 on 'Staff Participation in Strategy and Target Setting', compared to an average of 4.09 for all participating organisations. The low performance in the ranking provoked managers at State Corporation into action and a range of activities followed (Muniesa, 2014). The ranking system had performative effects and kicked off a trail of events inside State Corporation. 


\section{Figure 1: Benchmark Report for State Corporation}

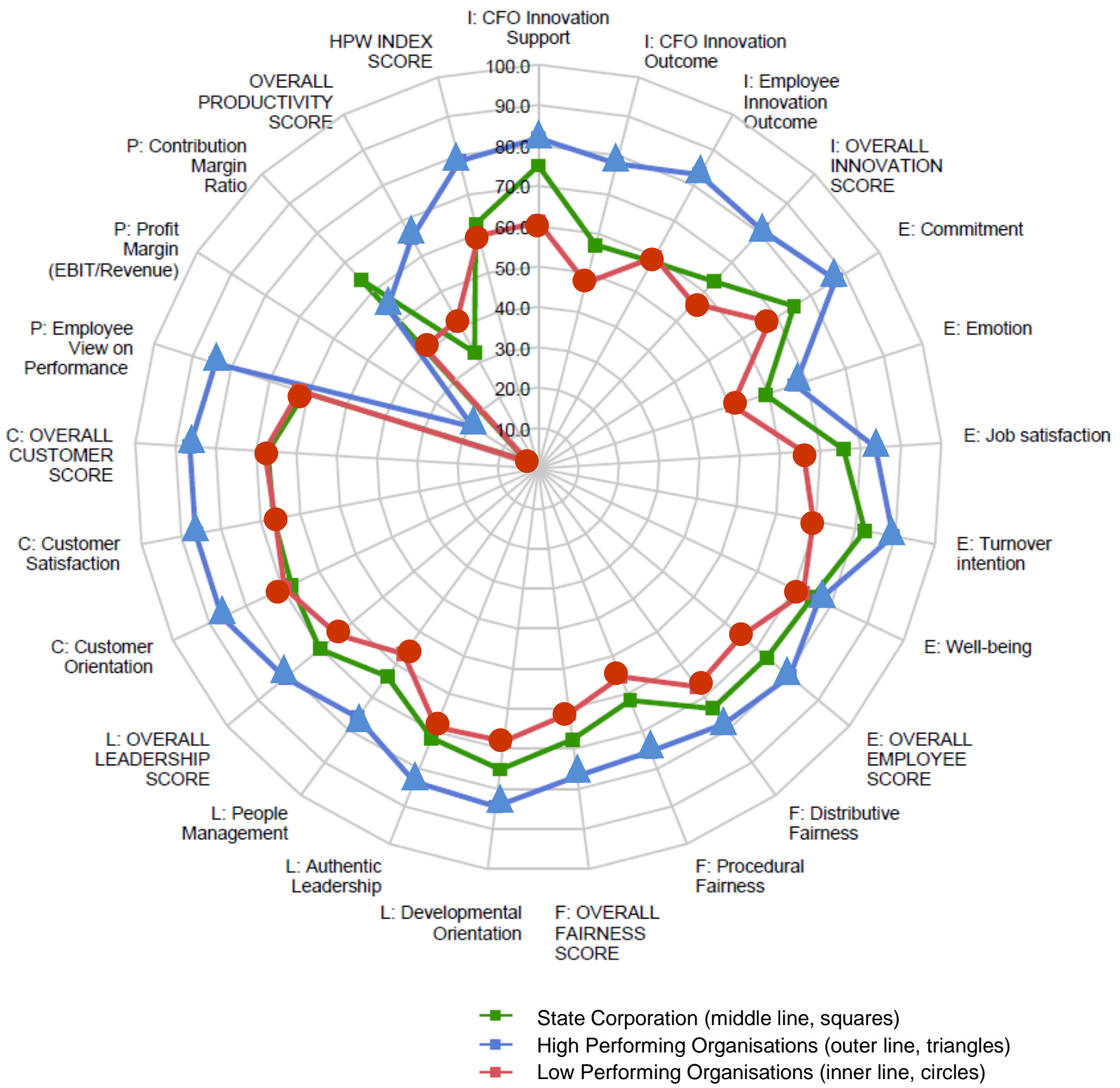

\subsection{Formulating the Three Intellectual Assets Strategies at State Corporation}

Based on State Corporation's results in the benchmark report, senior management formulated three intellectual asset strategies. These unfolded from January to July 2012 (see Table 2). During this time, the CEO described State Corporation as having gone from a company "that couldn't balance the books" and was "in threat of returning to government ownership", to one where today, "its audits and accounting departments are running efficiently" and where "the corporation is run independently at a management level". The CEO said that the next challenge for State 
Corporation was to introduce change to stimulate growth and to further strengthen the independence of the corporation. To do so, the CEO felt it was important to focus on the corporation's intellectual assets, including its customers and human capital.

Table 2: Timeline for Introducing the Three Intellectual Asset Strategies

\begin{tabular}{|c|c|}
\hline $\begin{array}{r}\text { March 2011: } \\
\text { October 2011: }\end{array}$ & $\begin{array}{l}\text { Benchmarking survey with staff } \\
\text { Corporate plan and strategy interventions first discussed at the Board } \\
\text { meeting }\end{array}$ \\
\hline November 2011: & Retreat to discuss the corporate plan \\
\hline $23^{\text {rd }}$ January 2012: & Meeting with consultants, discuss the Fusion Day \\
\hline $13^{\text {th }}$ February 2012: & Evening dinner for some of the Fusion Day participants \\
\hline $14^{\text {th }}$ February 2012: & Fusion Day at Darling Harbour \\
\hline $24^{\text {th }}$ February 2012: & Board meeting to confirm corporate plan \\
\hline $5^{\text {th }}$ March 2012: & Final meeting with consultants, discuss the post-Fusion Day activities \\
\hline $12^{\text {th }}$ March 2012: & Beginning of the Roadshow, starting in Dubbo. \\
\hline $24^{\text {th }}$ April 2012: & Maintenance and Services Fusion Day \\
\hline $30^{\text {th }}$ June 2012: & Business unit plans and individual work plans completed \\
\hline $30^{\text {th }}$ June 2012: & Finalisation of the corporate plan and sign-off by Board of Directors \\
\hline July 1, 2012 onwards: & Rollout of the corporate plan \\
\hline
\end{tabular}

The decision as to which intellectual asset strategies the corporation should pursue was debated during an internal meeting, chaired by the CEO and attended by two management consultants, the General Manager, Governance and Strategy, and the Manager, Human Resources. During this meeting, the CEO closely reviewed the results in the Intellectual Asset Health Check benchmark report and sought to clarify the meaning of its different categories. He asked: "What is meant by employee experiences?", "What is innovation and how is it different to new ideas?", and "How do we get managers to make these things their priority?" The CEO was somewhat critical of the benchmark report in that, whilst it provided valuable information, it failed to tell him "what to do next" or "how to do it". He felt that a more "structured framework" was needed to make the concept of intellectual assets meaningful to staff. As such, the deficiencies of the ranking system provoked further inquiry and this would be consistent with the tenants of incompleteness theory.

At the end of the meeting, the CEO tentatively announced that the corporation should introduce a new three-year organisation-wide corporate plan (2012-15), which 
would replace the existing corporate plan (2008-11) and that this plan, for the first time, would include intellectual assets as strategic priorities. This was the first time in history that a focus on intellectual asset had been introduced into State Corporation's strategy. Clearly, the ranking had performative effects.

During the meeting, the CEO also proposed three key focus areas for the 201215 corporate plan. The three areas were drawn from three criteria in the benchmark report, namely 'innovation', 'employee experiences' and 'customer orientation' (see Figure 1 again). The CEO referred to these areas as the 'intellectual asset strategies'. These three strategies were chosen because the benchmark report had identified them as areas of 'underperformance.' And so again, the ranking system generated not only discussion but also transformations inside State Corporation and this is entirely consistent with performativity theory.

Figure 2 below shows a reproduced version of the framework created to represent the three intellectual asset strategies in the new 2012-15 corporate plan. The idea was that each strategy would "filter down into initiatives", resulting in 'Strategic Initiatives' and 'KPIs'. This framework was created to meet the deficiencies of the benchmark report that failed to provide clear guidance on 'tactical actions' and 'next steps'. As such there was repair activity and attempts to mend the deficiencies or incompleteness of the benchmark report. The idea was to displace the benchmark report into a framework, which could then clearly articulate actions to staff and drive their work agendas. This however proved difficult, as discussed later. 
Figure 2: Framework for Representing the Intellectual Asset Strategies in the New Corporate Plan (2012-15)

\begin{tabular}{|l|l|l|}
\hline Intellectual Capital Strategies & Strategic Initiatives & $\begin{array}{l}\text { Corporate Key } \\
\text { Performance Indicators }\end{array}$ \\
\hline $\begin{array}{l}\text { Customer } \\
\text { Create tangible value for our } \\
\text { growth }\end{array}$ & \\
\hline $\begin{array}{l}\text { Employee Experience } \\
\text { Develop our people: safe and } \\
\text { engaged }\end{array}$ & & \\
\hline $\begin{array}{l}\text { Innovation } \\
\begin{array}{l}\text { Grow and promote our utility } \\
\text { business: broader profit base. }\end{array}\end{array}$ & \\
\hline
\end{tabular}

During the meeting, and also in subsequent interviews, the Manager, Strategy and Governance, reflected on the role of the intellectual asset benchmark report in deciding which intellectual assets should feature in the new corporate plan. She explained that the benchmark report identified several weaknesses that helped guide her work and determine the new corporate plan; so, clearly there was performativity in the sense that the ranking system influenced the decisions of actors. However, she also pointed out the difficulties she experienced in grappling with how to deliver a corporate plan endowed with intellectual assets for the first time:

...we talked about what sort of things to target, including what were the different things that we were trying to achieve here. I had only just arrived at this position and was grappling with how I was going to deliver a corporate plan when I have no experience, whilst I was also trying to deliver all this other stuff. And it emerged that the themes in the corporate plan were difficult to decide on without anyone having any fixed ideas, and so the benchmark report was a huge opportunity and really good. We already had a few things in mind for the corporate plan but then we went from there [the benchmark report] to how to roll out the plan and develop it, and it just kind of came together...in particular, for me, it [the benchmark report] has been really helpful... 
And so whilst there was performativity, there was also inquiry and some anxiety and nervousness about which targets and activities to pursue. Again, the incompleteness of the benchmark report rallied up support amongst managers. To further assist with this, management consultants were hired from a leading Australian consulting firm, which was highly regarded in the industry. The consultants believed that it was crucial for State Corporation to elevate intellectual assets to become a strategic priority if the corporation was to survive, grow and prosper. The consultants also played an important role in dealing with the angst that the ranking's incompleteness inevitably produced. A senior consultant reflected on her role in the process and suggested she acted as "a catalyst":

I felt in that meeting, as is quite common in our work, you're kind of like a catalyst - we come in like - we're a chemical ingredient, almost. It depends on the chemistry, on the connection, whether we can actually engage and partner with them.

A second consultant pointed out the need to "test" whether senior management was "serious" about the intellectual asset strategies or whether it was just "lip service". This consultant concluded that senior management seemed to be "genuinely" committed to the three new strategies.

...first of all, my approach - which was similar to my colleagues - is really testing out how fair dinkum they are, or is this just window dressing?

....what I was trying to do in the meeting was push that same line - like "how serious are you?" I raised the issue about trust and, essentially, not bullshitting people, "really, is that what it was about?" They seemed to connect with that. I came out of that with a sense of, "yeah, I think there is authenticity".

Also during the meeting, ideas for how senior management could "get buy in" from staff were discussed extensively and linked back to the benchmark report, which had identified remarkably low levels of staff participation in decision making. This was then a further point of anxiousness amongst the managers. This was then further linked 
to how, until now, the Board of Directors had micromanaged the strategy process with a very conservative mindset and how this, in the eyes of the new CEO, had stripped intellectual assets out of State Corporation. One of the management consultants explained:

...by that stage, they were a bit clearer about what they could do in terms of the Board. Because I think there was a lot of nervousness at the executive level around the barriers that the Board were putting up, in terms of what they could look at...

...there had been a history of the Board being very 'hands on' because the corporation was in crisis and they were worried about capability. But now the Board is feeling a sense of confidence in him [the CEO], so that's why there's a little bit more freedom for him. I think that's why the strategies are up for conversation and then input, rather than the Board micromanaging that...

Overall, at this point in time, the intellectual asset strategy seemed to be well organised and even if some hesitation and nervousness existed, management was reasonably confident with it. Consistent with the notion of performativity, the ideals put forth by the ranking system were sustained and a resulting increase in the future ranking numbers seemed very plausible at this stage.

\subsection{Counter-performativity at State Corporation}

Now that the intellectual asset strategies had been formulated, the next step was to implement them. This happened in several stages. As a first step, the CEO, together with the consultants organised a Fusion Day Workshop. The aim was to 'stress test' the three intellectual asset strategies and to secure 'buy-in' from staff (Consultant's Workshop Material). The consultants called this workshop the 'Fusion Day' to reflect the need to repair the longstanding distrust between maintenance staff (on the dam) and management (in the head office). At this point, the performativity of the ranking however started to come into question as other factors came into play. 
The Ghost from the Past

In 2007-2008, the corporation underwent a major restructure, which meant that staff had to be laid off. The restructure reduced operating costs and implied that approximately $18 \%$ of the workforce was laid off. This had created significant distrust between management and staff.

The Project Manager, Major Projects Group, commented:

It was a restructure that didn't need to happen. It was something that was forced on them... whilst there appeared to be consultation, there was no real consultation - it was a token gesture...the outcome was fairly damaging to the people in the organisation.

After the restructure, communication between management and workers on the dams had progressively worsened. Members of management used to visit the dams regularly. By the time of the restructure, all visits stopped. One worker on the dams explained:

.... the problem with State Corporation is who do you go to...because some of the managers...there's a bit of a trust thing because like I said before, they don't come and see you, they don't come and say, listen alright the boss isn't here, let's get together and have a bit of a talk and see what happens. That doesn't happen where it used to [Asset Field Officer, Dam Maintenance \& Services].

The regular visits by management to the dams were particularly important because of the remoteness and isolation of the outback areas and the big geographical distances between the dams and the corporate office. One staff member from the dams explained that working at State Corporation was like living in a prison. He felt lonely in the Australian outback, removed from his family and with little support from management. He said:

See, we're going through a stage now where we have a one in four roster where you live on site. I always say now I'd rather live in prison because you're away from your family and you're only getting peanuts to do it and it's like punishment [Asset Field Officer, Dam Maintenance \& Services]. 
This scepticism still played a significant role and negatively impacted staff's views on the intellectual asset strategies. Staff said that the previous corporate plan had left deep scars. The talk about a new corporate plan opened up old wounds and they felt they were re-living the past. The ranking system generated in this respect new anxieties and concerns that people were going to be laid off. This caused scepticism and resistance. Even though the period with the layoffs were a thing of the past, it still permeated people's thinking and operated as an intellectual 'liability' that was blocking any kind of progress. In the time that followed, many participants questioned whether the new strategies could be achieved at all and said they were 'somewhat optimistic'. One staff member said:

Cautious optimism, perhaps a little bit cynical - Oh here we go, it's another one of those processes. But we'll give it a go and see what happens. I think there is a lot of people in the organisation that are still burnt from the previous restructure [Project Manager, Major Projects Group].

This scepticism was echoed by another staff member:

Knowing the people in the organisation, knowing the mindset of the people also might look at this stuff thinking great, it sounds great but putting all of that in practice and achieving all of it, or even some of it...I could see immediately people would put up walls. It's almost like, Oh Geez, that's too big, too much, too fast, and remove themselves all together from it. I suppose it comes back to that old public sector mentality. I hate to use that term, but I think there's still a lot of that around [Project Manager, Major Projects Group].

Obviously, the corporation's history of low levels of trust in management by staff and poor communication were still problems that permeated the corporation in 2011. Such issues were not part of the framing of the ranking system. They were outside the system but they were still important. These issues caused renewed anxiety amongst staff which could end up jeopardising the intellectual asset project. Hard work was required in the face of mounting resistance and at this stage, performativity did not seem quite as easy; it certainly required extra efforts. 


\section{Feeling like a Fish out of Water}

The Fusion Day workshop was held at an upscale establishment in the capital's central business district. Forty-two employees from around the state and different work areas attended the workshop. The majority of attendees were male and of Caucasian heritage. Most of them wore jeans and a blue or grey shirt and had a solid frame. Early in the morning, they gathered in front of the establishment. They stood out from the office crowds passing through that part of the city on their way to work in their expensive business suits. The workers from the outback regions seemed noticeably uncomfortable in this upscale environment. They had their hands deep in their pockets and were nervously looking around. The rooms inside the venue were elegant with white tablecloths and spectacular views of the harbour through floor-to-ceiling glass windows. The grand entrance was covered in marble panels. A reading of the participant's body gestures and language suggested that they felt uncomfortable in this foreign environment.

The workshop required significant investment and was costly both financially (e.g., hiring of consultants, high-end venue and catering) and in terms of staff time. This investment was a symbolic gesture of the importance of the new intellectual asset strategy to the corporation and a decisive attempt at ensuring its performative effects.

During his opening presentation, the CEO showed the radar chart from the intellectual asset benchmark report (see again Figure 1) to the workshop participants. He explained the corporation's scores in each of the six categories of the ranking system and introduced the new intellectual asset strategies. Workshop participants listened, some with interest, and a few applauded the initiative to bring intellectual assets into the corporation. Some of the more sceptical staff commented that the low scores in the 
ranking system were of no surprise to them. During the presentation, the CEO also introduced the framework for the corporate plan (see again Figure 2) and explained that a critical aspect of the Fusion Day was to invite employees to participate in designing and reviewing the strategic initiatives and key performance indicators (KPIs) in the corporate plan. In doing so, the CEO showed a strong desire to involve the field officers from the Australian outback in decisions about the corporation's future. In his introductory speech, the CEO said:

I want your input...we are stress testing the strategic themes...we need your commitment to our plan going forward, you guys are the advocates of our business...you are here today, many employees are not, so you are the chosen ones...I know you are normally busy on the dance floor, now it's time to get up on the balcony with me and look into the future...

Having listened to the CEO, several field officers expressed their scepticism of management's ideas. Many covertly rejected the CEO's invitation to participate. Some commented that they felt 'like a fish out of water' and said they lacked knowledge of corporate work, let alone the abstract concept of strategy. The workers on the dam also said they saw little benefit of the intellectual asset strategies. In their world, all that mattered was to produce water and take care of the dams in a safe way. They struggled to see why State Corporation needed a strategy at all and criticised the money spent on flamboyant events, such as the Fusion Day. The performativity of the ranking was starting to be put into question.

When you go into that Fusion Day sometimes you are like a fish out of water. Some of the stuff that they talk about is office-based and we have nothing to do with it [Asset Field Officer, Dam Maintenance \& Services].

They were talking about...intent, Corporate Intent... what does that mean? This other corporate side of it, the real core business side of it...I just had no idea. I'm just not a business man...the terminology, the wording and all that (Manager, Dam Operations). 
Others saw it as an opportunity to further undermine the status of the CEO, who was looked upon by older staff members as a "young rookie". Field officers commented: "let's see if he can make it?", "he is still wet behind the ears" and "how long is he going to last?" As such there was opposition to the ranking and the strategy it had introduced. At this stage, its performative effects were increasingly uncertain.

The Manager, Strategy and Governance, acknowledged that the Fusion Day had limitations. She said:

...it's interesting, there are some guys on the dams...there were a lot in the group I was in...and they were really struggling to see the relevance of the rest of the plan, because what they do every day is go out and read a couple of measurements and send them back to dam safety, or they might grease some ropes or various different things, and their focus is safety. And their safety record is stellar, it's absolutely spectacular at the moment. And that's kind of what we want them to keep doing, want them to do what they are being told to do...

She also acknowledged:

"We're not a complicated organisation, we deliver water and we look after dams. It's pretty straightforward".

Similarly, the Manager, Customer Operations, explained:

Most people are operational type people, they can't buy into our strategies, they've got to buy in at the action level.

It seems that Callon (2010) is right. A performative statement needs to be mobilised by a whole network of actors for it to have broad based effects. And a lot of extra effort is required. And even lots of work does not guarantee success. In addition, as the ranking did not frame things of importance to the workers on the dam, they questioned the relevance of the ranking and its associated strategies. In effect, the ranking framed too little. Managers were suddenly faced with mounting resistance even 
if they had done all they could. Thus, the performativity of the ranking system was in question and the possibility of counter-performativity was increasingly likely.

\section{Pseudo Participation}

During the Fusion Day workshop, participants were assigned to groups to work on a specific part of the corporate framework and KPIs. This was a unique opportunity for staff to become actively involved and to mend the deficiency of the ranking by filling in gaps. Each group was given a poster. The poster featured two columns; one with Strategic Initiatives and one with KPIs (see again Figure 2). Both columns had been populated by senior management. For example, the poster for 'Develop Our People' had four Strategic Initiatives and eight KPIs. Despite being asked to add and revise the text on the posters, the workshop participants however did little to this effect. In the group assigned to the theme 'Develop Our People', participants added two words to the Strategic Initiatives ('capability' and 'information') and three KPIs (See Figure 3). They moved three of the existing KPIs into another box (for example, 'X\% increase in staff engagement' was moved from the third box to the first box under Strategic Initiatives (see Figure 3). All up, the changes were minor and no significant amendments were made. The group responsible for 'Growing the Business' struggled the most with this exercise. They overtly resisted it. Many sat with their arms crossed silently opposing the activity. Some stood up and left the group. The atmosphere was tense and uncomfortable. Specifically, the field officers from the water dams were reluctant and hesitant to say anything or put forth their views and ideas. 


\section{Figure 3: Framework in the New Corporate Plan (2012-15): Develop Our People}

\begin{tabular}{|c|c|c|}
\hline $\begin{array}{l}\text { Intellectual Capital } \\
\text { Strategies }\end{array}$ & Strategic Initiatives & $\begin{array}{c}\text { Corporate Key Performance } \\
\text { Indicators }\end{array}$ \\
\hline \multirow[t]{4}{*}{$\begin{array}{l}\text { Develop our people: } \\
\text { safe and engaged }\end{array}$} & $\begin{array}{l}\text { Develop leadership } \\
\text { capability that inspires } \\
\text { people to achieve }\end{array}$ & $\begin{array}{l}\text { - } \quad \mathrm{X} \% \text { reduction in turnover rate } \\
\text { - } \quad \mathrm{X} \% \text { reduction in sick leave } \\
\text { - } \quad \text { Number of nominations for } \\
\text { business awards }\end{array}$ \\
\hline & $\begin{array}{l}\text { Develop expertise in } \\
\text { emerging strategic } \\
\text { sectors - urban water, } \\
\text { carbon, energy, } \\
\text { information }\end{array}$ & $\begin{array}{ll}\text { - } & \text { Commercial unit fully } \\
\text { resourced } \\
\text { - } & \text { Business sponsors identified }\end{array}$ \\
\hline & $\begin{array}{l}\text { Build competent, safe } \\
\text { and engaged workforce }\end{array}$ & $\begin{array}{ll}- & \text { Zero lost time injury rate } \\
\text { - } & \text { X\% increase in staff } \\
\text { engagement } \\
\text { - } \\
\text { State Corporation fully } \\
\text { compliant with Work Health } \\
\text { and Safety Act requirements }\end{array}$ \\
\hline & $\begin{array}{l}\text { Ensure State Corporation } \\
\text { is engaged with the } \\
\text { broader community }\end{array}$ & $\begin{array}{l}\text { - } \quad \text { \# positive media mentions } \\
\text { - } \quad \mathrm{X} \% \text { of people involved in } \\
\text { individual and team charity } \\
\text { work } \\
\text { - } \quad \text { \$X contribution target }\end{array}$ \\
\hline
\end{tabular}

Note: Text in italics and arrows show the changes made by the workshop participants to the corporate plan proposed by the Senior Executives.

One staff member suggested adding a new KPI whereby managers in the capital city offices would be held accountable for their actions. Indeed, this staff member felt that management might not be needed at all. He wanted to do a management survey of State Corporation's management team:

...when you take a managerial position, you've got to be accountable for something. To me it feels like they're not. To me that can be a great KPI, it used to have that survey and for you as a manager to really succeed...this could be a way of being able to say, yes you're letting them know they're maybe not doing the best job...[Asset Field Officer, Dam Maintenance \& Services].

This suggests that the ranking system started to be used against management. Clearly, this was not a situation where the incompleteness of the ranking (and related KPIs) generating repair activity and succumbing managers to its agenda, as the incompleteness literature suggests. It was much more a situation of staff showing active 
resistance and seeking ways to block it. The ranking became in this respect a tool to mount and sustain resistance to management's strategy.

When asked if they felt empowered to have a say in the new strategies, participants again largely expressed scepticism. They said the Fusion Day was more about the CEO communicating his vision than genuinely seeking input from the staff:

Overall, I was pretty happy. I think I got a lot out of seeing the CEO's ideas on where he wants to take us and where the Board wants to take us. So that was really good to see that sort of stuff. As far as us having input, I thought maybe it was a little bit limited to a degree. They'd already sort of basically decided where they wanted to take the corporation and they were just after us to put words on maybe a piece of paper to a smaller degree. So yeah - I saw it as it was good for us to know where the CEO wanted to take us, rather than so much about us having input. Alright, we got to have a bit of input, but overall probably not a hell of a lot [Senior Asset Field Officer, Dam Maintenance \& Services].

I understand having people sitting in a room gets them involved, but it doesn't necessarily get buy-in and ownership - and I think the intention was to get buyin and ownership on the day. So if I had to score the day I'd give it a 6/10 [Manager, Customer Operations].

This is great what they want to do - I just hope they follow through with it. But I said they didn't really touch on what we do. The new CEO has never visited the dam [Asset Field Officer, Dam Maintenance \& Services].

One worker was particularly sceptical, suspecting that management was just pretending to be listening. He questioned the corporation's newly stated commitment to its human assets:

I think the biggest problem is you can listen but if you don't do anything what's the point in listening...I think that's what they're doing now. They listen but they don't [Asset Field Officer, Dam Maintenance \& Services].

When asked if she thought that staff felt empowered, the General Manager of Strategy and Governance replied:

I don't know. I think that...we talked about a lot of stuff...particularly in terms of business development...the Fusion Day, although they [the field officers] had the opportunity to change things, they didn't...there was some wording changes...so there was a blind spot... 
This mounting resistance made performativity difficult. This time marked the onset of counter-performativity because participants began to develop a dislike for the new strategies and turn the ranking system against management. While typically separated by space, the Fusion Day workshop brought people in remote locations together. And this made it possible to stage a more precise 'counter-mobilisation' of the ranking system and for staff to argue that State Corporation was in fact an antithesis to the ideals it articulated. Rather than generating support (and performativity), the ranking gave staff an opportunity to turn management's agenda on its head and further question their true intentions.

Despite the overt resistance by staff, on $30^{\text {th }}$ June, 2012, the new intellectual asset strategies and corporate plan were signed off by the Board of Directors and rolled out company-wide. This marked a significant milestone in the history of the corporation and symbolised the acknowledgement of the critical role of intellectual assets in its future.

However, for staff (especially the field officers out at the dams), the new intellectual capital strategies had changed very little in their way of thinking. This important group of staff did not share the CEO's enthusiasm about a more "glorious future" and they clearly had not bought into the three new intellectual asset strategies. Indeed, they doubted that the new strategies and corporate plan would bring about any real changes. The repair strategies produced by management were disbelieved. One Field Officer commented:

I suppose you've been getting a little bit, I wouldn't say negative, but realistic at times when you hear people say, we're going to do this, we're going to do that...yeah, it's great to hear it and it does lift you a little bit, but to actually see whether you do get there is another story and time will tell [Senior Asset Field Officer, Dam Maintenance \& Services].

Another Officer commented: 
A reasonable amount of the goals is realistic. You've obviously got to have goals and you've got to have targets that you want to get to. Whether we can actually get fully to those targets...we'll see it when we get there [Senior Asset Field Officer, Dam Maintenance \& Services].

One of the management consultants similarly expressed her concerns that the new agenda was at growing risk of not gaining broad-based traction and sustaining longevity within the organisation ${ }^{6}$. She commented:

...the experience of it before is that they're just on the corporate plan and they publish it and then that's it. Then it just sits there...and people lose faith if it doesn't get longevity... and they haven't got that cascade of where the executive member responsible for the business unit sort of takes it and then gets the involvement of everybody to craft their business unit and then has the conversation with individuals as to how their role connects to that. So without that, then of course you're not going to see your connection when you're down here to up here...

Even office workers had little faith that any substantial change had been achieved:

I don't think that it has really changed the way I'm doing things [Senior Communications Officer].

There was also scepticism as to whether the audacious goals were achievable in practice, particularly when the yearly floods came, raising the possibility of yet another threat that could block or derail the implementation of the new intellectual asset strategies.

Particularly when we've got floods - are they [the dam workers] actually available? That's going to be a challenge. Because we're planning at the end of the month in March...so if we get more rain, some of our guys might not actually be available [Manager, Human Resources].

\footnotetext{
${ }^{6}$ It should be noted that an initiative called the 'CEO Roadshow' was introduced following the Fusion Day in an attempt to ensure the new strategies would gain broad-based traction. The CEO and senior managers visited major sites in the outback to discuss intellectual capital strategies. Despite these efforts, the Manager, Strategy and Governance, said that she was disappointed by the lack of engagement from staff during the Roadshow. Few questions had been raised by the participants and she felt the Roadshow had not accomplished its aims.
} 
At this time, the consultants, whilst allies in the process of translation, started to make fun of the immaturity of the corporation. They explained they were "not being well managed" and that there was a "lack of clear timeframes, project milestones and agreed roles". One consultant commented:

Some things are hard. Like it is hard to get information, through the process. So, for instance, Natalie is supporting the General Manager, Strategy and Governance, and she is sort of our key point to try and get some of the data and information and names and things that kind of - but we need time ...... it is hard dragging stuff out. So there was, kind of [laughs], less of a priority around some things, to get that information. Because it is not the 'business as usual' kind of work, it is other stuff, and obviously they are not used to working with consultants. You can always tell a client that's not familiar with how consultants work...

In December 2013, two years and nine months after the original benchmark report was issued, State Corporation re-surveyed using the Intellectual Asset Health Check. The intention was to identify improvements in the corporation's ranking performance that had resulted from the new intellectual asset strategies. State Corporation received a second benchmark report showing their results.

Table 3 shows the results of the re-survey. It shows that State Corporation experienced a deterioration in performance in four out of five intellectual asset categories. There was a drop in Innovation of 10 percentage points; a drop in Employee Experience of 3 percentage points; a drop in Fairness of 2 percentage points; and a drop in Leadership of 2 percentage points. There was an increase in Customer Orientation of 3 percentage points; and an increase in Productivity and Profitability performance of 17 percentage points ${ }^{7}$.

The results showed that State Corporation had failed to achieve its stated intent of improving its ranking position despite the many investments made over a prolonged

\footnotetext{
7 The measure of productivity performance was a subjective employee measure. The results suggest that staff felt they were working harder and exerting more effort at work.
} 
period. Clearly, the three intellectual asset strategies had not delivered the effects desired by the CEO. The ranking system and the associated strategies had become decisively counter-performative. The ranking had motivated outcomes of reduced performance; not only different results, but contradictory results. The ranking was not merely a case of failure or misfire (Callon, 2010), it was a case of counterperformativity whereby the ranking system brought about results opposite to those espoused by its statement.

Table 3: Trends in State Corporation's Intellectual Asset Health Check Scores

\begin{tabular}{|l|c|c|c|}
\hline Categories & $\mathbf{2 0 1 0}$ & $\mathbf{2 0 1 3}$ & Trend \\
\hline Innovation & 57 & 47 & $\Downarrow$ \\
\hline Employee experience & 70 & 67 & $\Downarrow$ \\
\hline Fairness & 62 & 60 & $\Downarrow$ \\
\hline Leadership & 65 & 63 & $\Downarrow$ \\
\hline Customer orientation & 61 & 64 & $\uparrow$ \\
\hline Profitability \& productivity & 43 & 60 & $\uparrow$ \\
\hline
\end{tabular}

\section{Discussion}

Previous research on ranking systems has highlighted that a ranking system can reform the world in its image (e.g. Espeland \& Sauder, 2016; Kornberger \& Carter, 2010; Pollock \& D’Adderio, 2012; Sauder \& Espeland, 2007). This study shows a different type of performativity, namely that of counter-performativity. It also points towards the conditions which can mobilise an agenda of counter-performativity.

\subsection{Which Anxiety?}

The case of State Corporation shares with other research attention to anxiety as an engine for performativity. As demonstrated most comprehensively by Espeland and 
Sauder (Espeland \& Sauder, 2007; Espeland \& Sauder, 2016; Sauder \& Espeland, 2009), anxiety is pertinent to all those who participate in the market invented by the ranking system (see also Jeacle \& Carter, 2011; Scott \& Orlikowski, 2012). In Espeland and Sauder's case, anxiety happened because a market was under construction in which Law Schools were exposed to public scrutiny (Foucault, 1975). ${ }^{8}$ Marketisation persuaded Law Schools, and all their staff, to tolerate and act on the message by the ranking, even in circumstances where the rankings made their programmes more homogenised and they ended up providing less access to non-traditional students.

The case of State Corporation was different. Here, the ranking system did not reach into market-making as there was no market situation which disciplined the ranking's performativity. There was no public scrutiny by, or accountability to, external stakeholders and, as such, there were no reputational risks (Power, Scheytt, Soin \& Sahlin, 2009) at stake for State Corporation. Furthermore, the ranking system was anonymous and State Corporation did not know with whom it was ranked and therefore it could not reach out to attempt to learn from others in the cohort. Anonymity is what the firms wanted in order to participate. This is contrary to what literatures on benchmarking say about the usefulness of ranking, which is that it is conditional on the active comparison with identifiable others who differ in the ranking (Booth et al., 2005; Buckmaster \& Mouritsen, 2017; Laine \& Vinnari, 2014). Learning happens not vis-avis oneself but vis-a-vis others. This locates anxiety in relation to processes that differ between firms but which also unite a firm against others.

At State Corporation, the consequence of this was the possibility of counterperformativity. Rather than contemplating a market, which the CEO attempted to do,

\footnotetext{
${ }^{8}$ This is consistent with Foucault's (1975) argument that the visibility offered by reports and texts (here being the ranking system) plays a critical role in the exertion of disciplinary power. "......what was registered in this way were forms of behaviour, attitudes, possibilities, suspicions - a permanent account of individuals' behaviour." (Foucault, 1975, p. 214).
} 
the ranking system became an object that helped, not only employees but also consultants and certain managers, conclude that intellectual assets were not just meaningless words but unwise words implying incapable management. This turned out to be dangerous. The ranking did not provide settlement (as per Busco \& Quattrone, 2015); it provided absurd ideas about an intangible economy, which had no meaning to those who risked their lives working on the dams. In such a case, where anxiety was inward-looking, the controversy was much harder to settle because there was no external, common adversary, neither in the market (as in ranking) nor in the form of public accountability.

Furthermore, anxiety was backward-looking because the ranking system brought back memories of lay-offs and caused tensions to resurface. The ranking system reached not forward towards a common fate but backwards in a differentiated fate. Even if the narrative of intellectual assets was one in which the individual staff member played a constructive role, people saw it as pretence and front-stage, not as real. When anxiety extends backwards, it dilutes the focus on shared intent and a future orientation. This backward-looking focus was a second source of counterperformativity.

Anxiety was therefore related to the ranking system in such a way that its articulation made the world more, rather than less, uncertain. The ranking produced ambiguity and doubt. There was little learning and mostly tension. The ranking system ranked dimensions that were difficult to commensurate for all: not only for employees, who were furious, but also for consultants and managers, who developed additional processes that attempted to implement strategy. In the end, the intellectual assets, being those of human assets, customer orientation and innovation, seemed to lead to less thereof and to decrease rather than increase the corporation's ranking results. 
Thus, when anxiety is inwards- and backwards-looking, it has an uncertain orientation and then counter-performativity is more likely to occur. In such a case, calculative stringency is not enough; a tolerable problematisation is also required. The case of State Corporation offered plenty of devices for developing such a problematisation: a strategic framework for defining actions and KPIs, a narrative of organisational value and even safety issues for the Field Officers at the dams. But it disregarded other conditions, such as labour processes, the lack of trust in management and the fears of workers in the Australian outback, who felt abandoned and lonely. These kinds of intellectual 'liabilities' jeopardised the intellectual asset project. They were not part of the ranking system but they operated as practice (Gendron \& Barrett, 2004). Thus, in the case of State Corporation, the ranking system became counterproductive because it framed too little.

\subsection{Framing too little?}

Framing too little implies incompleteness (Ahrens \& Chapman, 2004; Busco \& Quattrone, 2018; Jordan \& Messner, 2012; Jørgensen \& Messner, 2010). The incompleteness of calculative technology permits a mediation that otherwise would be impossible. It engages users because of the organising work and action that it stimulates (Busco \& Quattrone, 2015). However, at State Corporation, the ranking system was not only performative in this sense. It was also counter-performative because it framed too little. This is important because then it is possible to understand the notion of incompleteness in a new way.

With the help of the ranking, it was possible for geographically dispersed employees to engage the history as something that was left out and to debate its lack of focus on important material assets. These issues were articulated via the ranking system 
and not outside of it. The very things that were intended to rectify relations between management and workers meant that the ranking became a source of protest, rather than progress. The ranking produced clarity and a language of 'all things wrong'. Its associated processes helped to develop links between otherwise dispersed employees, who together would develop new and adversarial interpretations of the state of affairs at State Corporation. It made it possible to develop 'counter-narratives'. The fact that employees were not 'involved enough' turned into a nightmare for managers who wrongly imagined that it would be possible to convince staff about the prosperity of a business-led agenda. In peculiar ways, the ranking system became a resource in the hands of employees, each of whom sought to find confirmation of the relevance of their history and to suggest that the corporation would never be a 'future-oriented' business but would remain a set of water-related assets.

Therefore, incompleteness does not invariantly lead to a search for more creative solutions and initiatives (Busco \& Quattrone, 2015, 2018; Jørgensen \& Messner, 2010). Incompleteness here clarified and reinforced a counter-narrative to a strategy based on material assets. This was in effect the 'old' strategy.' This clarity resulted in resentment about intellectual assets even if it ostensibly was about developing a better platform for individuals to grow. Individuals, however, did not agree and the repair strategies produced by management were disbelieved. Thus, in the case of State Corporation, incompleteness became a resource that, by not considering 'relevant' types of assets and liabilities, made the world clearer than it actually was; it brought a message that dams and water mattered little, and that labour processes and loneliness were irrelevant. This was counter-intuitive to employees and whilst repair work was not possible, the calculation was used in a counter-move to mobilise 'all things wrong'. 


\section{Conclusion}

Ranking systems are relative performance measures used to compare firms. When they are public, they help to create markets because managers orient themselves to the ranking numbers when they make decisions. This is a condition for performativity whereby firms are understood to abide with the ranking system so as to improve their performance.

However, in the case of State Corporation, the Intellectual Asset Health Check generated counter-performativity and resulted in a deterioration (rather than an improvement) of the corporation's performance in managing its intellectual assets. This happened partly because there was no comparison to which a collective effort would be oriented. Anxiety became internally (rather than externally) oriented. It happened partly because the ranking system, by being incomplete, was so clearly missing things of importance to the corporation, thus rallying people around the things that were missing. In the case of State Corporation, accounting was not an ammunition machine in which each stakeholder had a calculation (Burchell et al., 1980); and there was no discernible competition between calculations (Mouritsen, 1999; Mouritsen et al., 2009) nor overt conflict about the content of the calculation (Vinnari \& Skaerbaek, 2014) and, perhaps most notably, this was not a situation in which management could dominate labour via accounting systems and performance measures (Ezzamel et al., 2004, 2008). Instead, a calculation, such as the ranking system, was turned on its head, taken out of the hands of management and used against them.

This study shows in this regard that ranking systems are not inherently performative. There are 'felicity conditions' (Callon, 2010), which need more attention in research. 'Felicity conditions' may prompt attention to who, what and how resistance 
is performed. It may be about the strength of the depiction of the ranking system to include relevant assets; it may also be about both the presence and absence of conditions.

Last, to trace performativity, it is not enough to only focus on executive or senior managers because the chain of events can derail and stop at any point. Future studies can investigate differences in the nature of transformations and disruptions created by actors close and afar. Are all transformations generative or can they be disruptive? Why do workers in some organisations exercise overt resistance (e.g. Ezzamel et al., 2004 and this study) whilst in others, workers participate in the creation of performative hegemony (e.g. Boedker \& Chua, 2013; Cushen, 2013; McCabe, 2011)? 


\section{References}

Aggarwal, R. K., \& Samwick, A. A. (1999). Executive compensation, strategic competition, and relative performance evaluation: Theory and evidence. The Journal of Finance, 54(6), 1999-2043.

Ahrens, T., \& Chapman, C. S. (2004). Accounting for flexibility and efficiency: A field study of management control systems in a restaurant chain. Contemporary Accounting Research, 21(2), 271-301.

Ahrens, T., \& Chapman, C. S. (2007). Management accounting as practice. Accounting, Organizations and Society, 32(1-2), 1-27.

Aldridge, A. (1994). The construction of rational consumption in Which? magazine: The more blobs the better? Sociology, 28(4), 899-912.

Andon, P., Baxter, J., \& Chua, W. F. (2007). Accounting change as relational drifting: A field study of experiments with performance measurement. Management Accounting Research, 18, 273-308.

Andrew, J., \& Cahill, D. (2017). Rationalising and resisting neoliberalism: The uneven geography of costs. Critical Perspectives on Accounting, 45, 12-28.

Antal, A. B., Hutter, M., \& Stark, D. (2015). Moments of Valuation: Exploring Sites of Dissonance. Oxford: Oxford University Press.

Amernic, J. H. (1985). The roles of accounting in collective bargaining. Accounting, Organizations and Society, 10(2), 227-253.

Austin, J. L. (1962). How To Do Things with Words. Oxford: Clarendon Press.

Bamford, A., \& MacKenzie, D. A. (2018). Counterperformativity. New Left Review, 113(sept/oct), 97-121.

Becker, S. H. (1984). Art Worlds. CA: University Presses of California, Columbia and Princeton.

Blank, G. (2006). Critics, Ratings, and Society: The Sociology of Reviews. United States: Rowman \& Littlefield.

Boedker, C., \& Chua, W. F. (2013). Accounting as an affective technology: A study of circulation, agency and entrancement. Accounting, Organizations \& Society, 38(4), 245-267.

Booth, M., James, P., \& Stevanovic, V . (2005). Benchmarking of hospital activity data: An international comparison. Benchmarking: An International Journal, 12(6), $515-522$.

Bourmistrov, A., \& Kaarbøe, K. (2013). From comfort to stretch zones: A field study of two multinational companies applying "beyond budgeting" ideas. Management Accounting Research, 24(3), 196-211.

Buckmaster, N., \& Mouritsen, J. (2017). Benchmarking and learning in public healthcare: Properties and effects. Australian Accounting Review, 27(3), 232-247.

Burchell, S., Clubb, C., Hopwood, A. G., Huges, J., \& Nahapiet, J. (1980). The roles of accounting in organizations and society. Accounting, Organizations and Society, 5(1), 1-25.

Busco, C., \& Quattrone, P. (2015). Exploring how the Balanced Scorecard engages and unfolds: Articulating the visual power of accounting inscriptions. Contemporary Accounting Research, 32(3), 1236-1262.

Busco, C., \& Quattrone, P. (2018). In search of the "Perfect One": How accounting as a maieutic machine sustains inventions through generative "in-tensions." Management Accounting Research, 39, 1-16.

Busco, C., Quattrone, P., \& Riccaboni, A. (2007). Management accounting. Issues in 
interpreting its nature and change. Management Accounting Research, 18(2), 125149.

Callon, M. (1998). Introduction: the embeddedness of economic markets in economics. In M. Callon (Ed.), The Laws of the Market (pp. 1-57). Oxford: Blackwell/The Sociological Review.

Callon, M. (2007). What does it mean to say that economics is performative? In D. A. MacKenzie, F. Muniesa, \& L. Siu (Eds.), Do Economists Make Markets? On the Performativity of Economics (pp. 311-357). Princeton and Oxford: Princeton University Press.

Callon, M. (2010). Performativity, misfires and politics. Journal of Cultural Economy, 3(2), 163-169.

Carter, M., Ittner, C., \& Zechman, S. (2009). Explicit relative performance evaluation in performance-vested equity grants. Review of Accounting Studies, 14(2), 269-306.

Chua, W. F. (1995). Experts, networks and inscriptions in the fabrication of accounting images: A story of the representation of three public hospitals. Accounting, Organizations and Society, 20(2-3), 111-145.

Cooper, C. (2015). Accounting for the fictitious: A Marxist contribution to understanding accounting's roles in the financial crisis. Critical Perspectives on Accounting, 30, 63-82.

Cooper, D. J., \& Essex, S. (1977). Accounting information and employee decision making. Accounting, Organizations and Society, 2(3), 201-217.

Cooper, D. J., \& Sherer, M. J. (1984). The value of corporate accounting reports: Arguments for a political economy of accounting. Accounting, Organizations and Society, 9(3-4), 207-232.

Creswell, J. W., \& Miller, D. L. (2000). Determining validity in qualitative inquiry. Theory Into Practice, 39, 124-130.

Cushen, J. (2013). Financialization in the workplace: Hegemonic narratives, performative interventions and the angry knowledge worker. Accounting, Organizations and Society, 38, 314-331.

Dambrin, C., \& Robson, K. (2011). Tracing performance in the pharmaceutical industry: Ambivalence, opacity and the performativity of flawed measures. Accounting, Organizations and Society, 36(7), 428-455.

Espeland, W. N., \& Sauder, M. (2007). Rankings and reactivity: How public measures recreate social worlds. American Journal of Sociology, 113(1), 1-40.

Espeland, W. N., \& Sauder, M. (2016). Engines of Anxiety: Academic Rankings, Reputation, and Accountability. Russell Sage Foundation.

Ezzamel, M., Willmott, H., \& Worthington, F. (2004). Accounting and managementlabour relations: The politics of production in the 'factory with a problem'. Accounting, Organizations and Society, 29(3-4), 269-302.

Ezzamel, M., Willmott, H., \& Worthington, F. (2008). Manufacturing shareholder value: The role of accounting in organizational transformation. Accounting, Organizations and Society, 33(2-3), 107-140.

Ferlie, E., Pettigrew, A., Ashburner, L., \& Fitzgerald, L. (1997). The new public management in action. Long Range Planning, 30(1), 145-146.

Fischer, M. D., \& Ferlie, E. (2013). Resisting hybridisation between modes of clinical risk management: Contradiction, contest, and the production of intractable conflict. Accounting, Organizations and Society, 38(1), 30-49.

Foucault, M. (1975). Discipline and Punish. Random House Group.

Free, C., Salterio, S., \& Shearer, T. (2009). The construction of auditability: MBA 
rankings and assurance in practice. Accounting, Organizations and Society, 34(1), 119-140.

Gendron, Y. \& Barrett, M. (2004). Professionalization in action: Accountants' attempt at building a network of support for the WebTrust seal of assurance. Contemporary Accounting Research, 21(3), 563-602.

Gibbons, R., \& Murphy, K. J. (1990). Relative performance evaluation for chief executive officers. ILR Review, 43(3), 305-515.

Grey, C. (2009). Licence to think. Management Learning, 40(4), 353-356.

Guest, G., Bunce, A., \& Johnson, L. (2006). How many interviews are enough? An experiment with data saturation and variability. Field Methods, 18(1), 59-82.

Hazelkorn, E. (Ed.). (2015). Rankings and the Reshaping of Higher Education: the Battle for World-Class Excellence. (2nd ed.). London: Palgrave Macmillan.

Hines, R. D. (1988). Financial accounting: In communicating reality, we construct reality. Accounting, Organizations and Society, 13(3), 251-261.

Hopwood, A. G. (1972). An empirical study of the role of accounting data in performance evaluation. Journal of Accounting Research, 10, 156-182.

Hyndman, N., \& Lapsley, I. (2016). New Public Management: The story continues. Financial Accountability and Management, 32(4), 385-408.

Jeacle, I., \& Carter, C. (2011). In TripAdvisor we trust: Rankings, calculative regimes and abstract systems. Accounting, Organizations and Society, 36, 293-309.

Jordan, S., \& Messner, M. (2012). Enabling control and the problem of incomplete performance indicators. Accounting, Organizations and Society, 37(8), 544-564.

Jørgensen, B., \& Messner, M. (2010). Accounting and strategising: A case study from new product development. Accounting, Organizations and Society, 35, 184-204.

Karpik, L. (2010). Valuing the Unique: The Economics of Singularities. Princeton University Press.

Kornberger, M., \& Carter, C. (2010). Manufacturing competition: How accounting practices shape strategy making in cities. Accounting, Auditing \& Accountability Journal, 23(3), 325-349.

Laine, M., \& Vinnari, E. (2014). The dynamics of voluntary benchmarking in the water sector. Public Money \& Management, 34(4), 297-304.

Latour, B. (1986). Visualisation and cognition: Drawing things together. Knowledge and Society: Studies in the Sociology of Culture and Present, 6, 1-40.

Latour, B. (1987). Science in Action. How to Follow Scientists and Engineers Through Society. Cambridge, Mass.: Harvard University Press.

Lépinay, V. (2007). Decoding finance: Articulation and liquidity around a trading room. In D. MacKenzie, F. Muniesa, \& L. Siu (Eds.), Do Economists Make Markets?, On the Performativity of Economics (pp. 87-127). Princeton, N.J: Princeton University Press.

Llewellyn, S., \& Northcott, D. (2005). The average hospital. Accounting, Organizations \& Society, 30, 555-583.

Locke, W. (2011). The institutionalization of rankings: managing status anxiety in an increasingly marketized environment. In J. C. Shin \& R. K. Toutkoushian (Eds.), University Rankings: Theoretical Basis, Methodology and Impacts on Global Higher Education. The Changing Academy - The Changing Academic Profession in International Comparative Perspective (pp. 201-228). Dordrecht, Netherlands: Springer.

MacKenzie, D. A. (2006). An Engine Not a Camera: How Financial Models Shape Markets. MIT Press: Cambridge, Massachusetts, London, England.

MacKenzie, D. A. (2007). Is economics performative? In D. MacKenzie, F. Muniesa, 
\& L. Siu (Eds.), Do Economists Make Markets?, On the Performativity of Economics (pp. 54-86). Princeton, N.J: Princeton University Press.

MacKenzie, D. A., \& Millo, Y. (2003). Constructing a market, performing a theory: The historical sociology of a financial derivatives exchange. Americal Review of Sociology, 109(1), 107-145.

Marginson, S., \& van der Wende, M. (2007). To rank or not be ranked: The impact of global rankings in higher education. Journal of Studies in Higher Eduation, 11(3), 306-329.

McCabe, D. (2011). Accounting for consent: Exploring the reproduction of the labour process. Sociology, 45(3), 430-446.

Miles, M. B., Huberman, A. M., \& Saldana, J. (2013). Qualitative Data Analysis: A Methods Sourcebook. SAGE Publications, Incorporated.

Miller, P. (1991). Accounting and objectivity. The invention of calculating selves and calculable spaces. Annals of Scholarship, 9, 61-85.

Miller, P., \& Power, M. (2013). Accounting, organizing, and economizing. The Academy of Management Annals, 7(1), 557-605.

Miller, P. B., \& Rose, N. (1990). Governing economic life. Economy and Society, 19(1), 1-31.

Millo, Y., \& MacKenzie, D. A. (2009). The usefulness of inaccurate models: Towards an understanding of the emergence of financial risk management. Accounting, Organizations and Society, 34(5), 638-653.

Mouritsen, J. (1999). The flexible firm: strategies for a subcontractor's management control. Accounting, Organizations and Society, 24(1), 31-55.

Mouritsen, J., Hansen, A., \& Hansen, C. Ø. (2009). Short and long translations: Management accounting calculations and innovation management. Accounting, Organizations and Society, 34(6/7), 738-754.

Mouritsen, J., \& Kreiner, K. (2016). Accounting, decisions and promises. Accounting, Organizations and Society, 49(1), 21-31.

Muniesa, F. (2014). The Provoked Economy: Economic Reality and The Performative Turn. New York: Routledge.

Munro, R. (1995). Managing by ambiguity: An archaeology of the social in the absence of management accounting. Critical Perspectives on Accounting, 6(5), 433-482.

Oakes, L., Townley, B., \& Cooper, D. J. (1998). Business planning as paedagogy: Language and control in a changing institutional field. Administrative Science Quarterly, 43(2), 241-275.

Owen, D. L., \& Lloyd, A. J. (1985). The use of financial information by trade union negotiators in plant level collective bargaining. Accounting, Organizations and Society, 10(3), 329-350.

Patton, M. Q. (1990). Qualitative Evaluation and Research Methods. SAGE Publications, Incorporated.

Perlow, L. A. (1998). Boundary control: The social ordering of work and family time in high-tech corporation. Administrative Science Quarterly, 43(2), 328-357.

Pollock, N., \& D'Adderio, L. (2012). Give me a two-by-two matrix and I will create the market: Rankings, graphic visualisations and sociomateriality. Accounting, Organizations and Society, 37(8), 565-586.

Pollock, N., \& Williams, R. (2009). The sociology of a market analysis tool: How industry analysts sort vendors and organize markets. Information and Organization, 19(2), 129-151.

Pollock, N., D’Adderio, L., Williams, R., \& Leforestier, L. (2018). Conforming or transforming? How organizations respond to multiple rankings. Accounting, 
Organizations and Society, 64, 55-68.

Power, M., Scheytt, T., Soin, K., \& Sahlin, K. (2009). Reputational risk as a logic of organizing in late modernity. Organization Studies, 30, 301-324.

Quattrone, P. (2009). Books to be practiced: Memory, the power of technical, and the success of accounting. Accounting, Organizations and Society, 34(1), 85-118.

Quattrone, P. (2017). Embracing ambiguity in management controls and decisionmaking processes: On how to design data visualisations to prompt wise judgement. Accounting Business Research, 47(5), 588-612.

Quattrone, P., \& Hopper, T. (2001). What does organisational change mean?

Speculations on a taken for granted category. Management Accounting Research, 12(4), 403-435.

Quattrone, P., \& Hopper, T. (2005). A "time-space odyssey": management control systems in two multinational organisations. Accounting, Organizations and Society, 30(7-8), 735-764.

Revellino, S., \& Mouritsen, J. (2015). Accounting as an engine: The performativity of calculative practices and the dynamics of innovation. Management Accounting Research, 28, 31-49.

Roberts, J., \& Jones, M. (2009). Accounting for self interest in the credit crisis. Accounting, Organizations and Society, 34(6), 856-867.

Sauder, M., \& Espeland, W. N. (2009). The discipline of rankings: Tight coupling and organizational change. American Sociological Review, 74(1), 63-82.

Schultz, M., Mouritsen, J., \& Gabrielsen, G. (2001). Sticky reputation: Analyzing a ranking system. Corporate Reputation Review, 4(1), 24-41.

Scott, S. V., \& Orlikowski, W. J. (2012). Reconfiguring relations of accountability: Materialization of social media in the travel sector. Accounting, Organizations and Society, 37(1), 26-40.

Shollo, A., Constantiou, I., \& Kreiner, K. (2015). The interplay between evidence and judgment in the IT project prioritization process. The Journal of Strategic Information Systems, 24(3), 171-188.

Shrum, W. M. (1996). Fringe and Fortune: The Role of Critics in High and Popular Art. Princeton, N.J: Princeton University Press.

Skaerbaek, P., \& Tryggestad, K. (2010). The role of accounting devices in performing corporate strategy. Accounting, Organizations and Society, 35(1), 108-124.

Themsen, T. N., \& Skaerbaek, P. (2018). The performativity of risk management frameworks and technologies: The translation of uncertainties into pure and impure risks. Accounting, Organizations and Society, 67, 20-33.

Vaivio, J. (1999). Examining "The quantified customer". Accounting, Organizations and Society, 24, 689-715.

Veal, J. (2005). Business Research Methods: A Managerial Approach ( $2^{\text {nd }}$ ed.). Pearson Education Australia.

Vinnari, E., \& Skaerbaek, P. (2014). The uncertainties of risk management: A field study on risk management internal audit practices in a Finnish municipality. Accounting, Auditing \& Accountability Journal, 27(3), 489-526.

Vosselman, E. (2014). The 'performativity thesis' and its critics: Towards a relational ontology of management accounting. Accounting and Business Research, 44(2), 181-203.

Wedlin, L. (2011). Going global: Rankings as rhetorical devices to construct an international field of management education. Management Learning, 42, 199-218.

Wouters, M., \& Wilderom, C. (2008). Developing performance-measurement systems as enabling formalization: A longitudinal field study of a logistics department. 
Accounting, Organizations and Society, 33(4-5), 488-516. 